\title{
Estimation of the Black Economy of Pakistan through the Monetary Approach
}

\author{
MEHNAZ AHMED and QAZI MASOOD AHMED
}

\section{INTRODUCTION}

In the recent years the "black economy" has held immense attraction for academics as well as policy-makers. This is because the presence of the black economy is responsible for distortions in the official estimates of macro-economic variables like income generation, employment, rate of inflation, etc., and thus the possible effect on the economic policies cannot be ascertained properly. It, therefore, becomes imperative to investigate this area of research.

Researchers have defined the underground economy in alternative ways. The underground economy defined by varied names like black, shadow, hidden, informal, clandestine, second, parallel economy has been divided in four categories for the use of a standard basis of classification [Feige (1990)].

\section{(a) The Illegal Economy}

It consists of income produced by those form of economic activities which are anti-social in nature, through violation of legal statutes. The most prominent of all activities in this type of underground economy is drug trafficking. The production of drugs provides a huge sum of money which competes with the production of other crops. Besides this, it includes smuggling of various goods and currency, prostitution, etc.

\section{(b) The Unreported Economy}

Governments all around the world forfeit enormous amount of revenues through uncollected taxes. This is due to the presence of the unreported economy, operating side by side with the official economy. The unreported economy or the black economy comprises those activities that circumvent or evade the payment of taxes, breaking the fiscal rules. It includes income which should be reported to the authorities but is not. The size and growth of black economy adversely affects various economic and tax reform policies, the budget deficit, and debt burden, etc.

Mehnaz Ahmed is based at the Sustainable Development Policy Institute, Islamabad. Qazi Masood Ahmed is based at the Applied Economics Research Centre, University of Karachi. 
Research conducted in this area suggests that there should be simplification of tax laws, lowering of tax rates, and broadening of the tax base and lowering of the administrative cost of the efficiency system.

\section{(c) The Unrecorded Economy}

This type of the underground economy includes those activities which are concerned with the problems relating to the rules and regulations of the reporting requirements of statistical agencies. It includes that income which should be recorded in the national accounts but is not included. The unrecorded income is the difference between the actual amount or output and the amount measured by the statistical system.

The current method of assessing the gross national product is not satisfactory as it does not cover all the economic activities of the economy. Important elements escape the measurement of these macro-economic instruments. Similarly, if the correct measurement of labour is made and those operating in the hidden economy are taken into account, then it would give the right direction to the government in designing policies for unemployment. Planning the gross national product of any country and its pace of growth, the level of inflation and unemployment, formulation of a policy for income and wages, etc., all require decisions to be made on the basis of available data. With the unreliability of the data known, the social welfare policies and other targets set by the government can be disappointing.

One of the most important elements of this income is household production which is not included in the national accounts due to the difficulties encountered in its measurement. In this way, the unrecorded economy biases the estimates of the variables like unemployment rates, savings rates, etc.

\section{(d) The Informal Economy}

It comprises those activities that entail a cost but are excluded from the benefits and rights of the formal activities. They may emerge as informal housing, informal transport, informal industrial sector, etc. These activities are illegal in nature but are not anti-social like drug trade, smuggling, etc. De Soto (1989) studied the informal economy of Peru and confined his analysis to the informal sector in urban areas only, whereas informality also prevails in the rural areas. Policy actions can have significant positive or negative impacts on the activity of the informals, because the emergence of the informal sector is mainly due to the laws and regulations passed in the interest of the privileged èlite of the country.

It is imperative to study the black economy. Research can prove its existence, its quantification according to the information available, and it can describe its patterns of behaviour and explain the reasons for its growth. Such work will be useful to the policymakers as it will provide guidelines about the potential of the economy to generate resources that escape ordinary measurement. 
Much research has been carried out for estimation of the black economy in developed countries, but this area yet remains to be explored in the context of developing countries. In the case of Pakistan, rough estimates of the black economy are obtained from the reports of the National Taxation Reform Commission, which are based on mere deductions derived from the possible indications available. It is in this background that the present study attempts to carry out a comprehensive and sophisticated analysis to estimate the black economy of Pakistan.

In the light of the discussion above, we have estimated the black economy that falls in the category of unreported economy, which can be defined as comprising those activities which are disguised from the tax authorities with a view to evading the payment of taxes. Our study has attempted to measure the black economy by replicating, with some modifications, Vito Tanzi's method, as this method is considered to be the most refined work done in the area of monetary analysis so far and was originally applied to the black economy of the USA.

The paper is organised as follows: Section 2 reviews the literature, Section 3 explores the methodology, Section 4 explains the empirical results, and Section 5 gives the conclusion.

\section{REVIEW OF LITERATURE}

Explained below are the monetary methods by which researchers have measured the size of the black economy so far.

\section{(i) The Gutmann Method}

Gutmann (1977) estimated the underground economy of United States in 1974 and gave a provocative estimate of $\$ 200$ billion. His analysis is based on four key assumptions:

(i) The medium of exchange in the underground economy is mainly based on currency.

(ii) The activities in the underground economy are the consequences of high taxes and government-imposed restrictions.

(iii) The ratio of currency to demand deposits is influenced only by the changes in taxation and other restrictions imposed by the government since 1937-41 and by nothing else.

(iv) The period of 1937-41 was the one in which there was no underground economy and is termed as the benchmark period.

With these assumptions, he calculated the hidden economy by first calculating the ratio of currency to demand deposits for the benchmark period of 1937-41 and then estimated the currency to demand deposits of 1976. He assumed that the level of demand deposits was normal and then calculated the extra currency attributable to the existence of the black economy by taking the difference between the ratios of currency 
to demand deposits of 1976 to the benchmark period. The extra currency was then multiplied by the ratio of legal GNP to legal money (excluding extra currency). The result gave the extent of the black economy.

The approach is criticised on the basis of the assumptions by Feige (1979), as follows:

According to Feige, Gutmann's first assumption is unrealistic since most of the black money is transferred aboard and is then brought in the country by creation of loans for the business. This, in turn, requires demand deposits, which affect the ratio of currency to demand deposits. It is also probable that irregular purchases can take place by cheque, with little risk of detection.

Gutmann's third assumption is criticised because the ratio of currency to demand deposits changes over time due to various factors, as it is also suggested by Philip Cagen, like the volume of retail sales, urbanisation, trade, bank failures, cost of holding currency and demand deposits. Tanzi (1981) has stressed the fact that Gutmann's strong case turns weak if the price changes are taken into account. Thus, once the price changes are adjusted, the per capita currency holding shows a decline. Gutmann had not taken account of that. Besides, if the benchmark period is changed, then the results would vary. In this way, the results become sensitive to the choice of the initial period.

It has been observed that the increase in the ratio of currency to demand deposits is due to a greater fall in the demand deposits than to an increase in currency. Given the case with which deposits could be transferred between demand and time, it is seen, in the context of the United States, on which Gutmann's study is based, that many depositors have decreased the holding of demand deposits and have increased that of time deposits on which interest can be earned.

The third assumption is questionable because the ratio of currency to demand deposits had also changed over time due to the change in the composition of currency in circulation, the reason being that a great part of the currency, i.e., dollar bills, are held outside the country (United States). The explanation for this behaviour of currency, especially the $\$ 100$ bills, is: First, in some countries like Panama, Liberia, etc., American currency circulates as freely as local currency. Second, foreign trades creates an increase in the demand for large denomination bills, and foreign travel has increased to a great extent in the last few years. Third, the increase in oil revenue accruing to the Middle East is in the forms of dollars. Fourth, countries in which imports are restricted have, in recent years, introduced import systems where importers are given import permits to import goods by the use of foreign currency, especially dollars. Fifth, some countries have introduced duty-free zones where by goods are sold duty-free only if the payments are made in foreign currency, which again means dollars. Sixth, large incomes desired from illegal activities, such as drugs, are usually converted in large bills which are smuggled out of the country. Finally, the high rate of inflation in most countries has led to currency substitution, i.e., dollars are replaced often by domestic currency. 


\section{(ii) The Feige Method}

According to Feige (1979) the total transactions in the economy can be measured by adding the volume of cheque transactions (demand deposits times the average turnover of these deposits) to the volume of currency transactions (currency in circulation times the average turnover of currency). The volume of checking transactions can be derived from the knowledge of the stock of the demand deposits and estimates of the average number of times per year the turnover of the demand deposits. The turnover rates were available since 1919 for the United State. Currency turnover was obtained by calculating the total number of times an average unit of currency changes hands before its quality deteriorates and it is retired from calculation. Robert Laurent has estimated that during the period of 1890-1965 the number of physical transfers that a unit of currency could perform before retirement was approximately 125 turnovers. Feige's analysis of underground economy for United States is based on the quantitative theory of money developed by Irving Fisher as:

$$
M V+M^{\prime} V^{\prime}=P T
$$

Where

$$
\begin{aligned}
M= & \text { Currency notes. } \\
M^{\prime}= & \text { Demand deposits. } \\
V= & \text { Velocity of money of the currency notes or the average turnover on the } \\
& \text { currency. } \\
V^{\prime}= & \text { Velocity of money of the demand deposits or the average turnover on the } \\
& \text { demand deposits. } \\
P= & \text { Composite price index of existing and newly created goods. } \\
T= & \text { Physical volume of transaction. }
\end{aligned}
$$

Firstly, Feige determines $M, M^{\prime} V$ and $V^{\prime}$ and from this he deduces $P T$. This $P T$ is then divided by the observed income to GNP, which gives the estimate of the underground economy. The observed income py is the product of the price index of newly created goods and services and $y$ is the real income.

Thus if $M V$ is known, $P T$ can be evaluated. In the absence of the underground economy, the nominal GNP derived should be equal to the officially measured GNP. Feige had assumed that there was no underground economy in the period of 1939 and found that the ratio of $P T / G N P$, estimated to be (10.3), was normal. He then calculated the GNP for 1976 and 1978. Dividing the results by the 1939 ratio, he derived the nominal GNP measured indirectly. The difference between the indirectly measured GNP and the official one in the national accounts gave the estimate of the underground economy.

Feige himself admits that the calculations that he has done are in need of refinement: 
1. It is assumed in the analysis that the velocity of official and unofficial sectors is equal, but if it is larger, then this will make the figure for the underground economy higher.

2. Recent financial innovations have probably induced a larger number of transactions between various types of liquid assets. Adjustments of such increase again would reduce the estimate of the black economy.

3. The barter transactions are not included in the analysis which has led to an understatement of the hidden economy.

Gutmann (1979) had criticised Feige's analysis, which begins by shedding light on the total value of economy's transactions. This in turn depends on the turnover rates of demand deposits and of currency, since no details are given in his calculation of demand deposit turnover rates other than noting that he had eliminated the major financial centres. Thus it is not possible to carry out his calculations through to their results.

Then the turnover rates of currency are not known. Feige arrived at the solution to this problem by adopting the estimate of Laurent which includes the number of physical transfers that a unit currency could perform before retirement. This estimate is quite questionable, because Laurent had made an unrealistic assumption that the quality of the paper in the country has not changed since before World War II. But when Feige discovered that the quality of paper did in fact change drastically, he doubled Laurent's estimate of the number of physical transfers that currency could perform, which doubled the currency turnover rates that affect the estimates of the subterranean economy.

Feige assumes that the ratio between the volume of transactions and the GNP (legal plus subterranean) has remained constant from before World War II to the period selected. Hence any increase in the ratio of the volume of transactions to the legal GNP must be due to the uncounted subterranean GNP. This assumption is analogous to the third assumption made by Gutmann.

Tanzi has laid criticism at Feige's analysis by pointing out the fact that his results are sensitive to the choice of the initial period. If the period is changed, the analysis will vary.

\section{(iii) The Tanzi Method}

Tanzi $(1980$; 1983) has refined the estimates of the black economy using the currency ratio, which in turn is based on an earlier insight of the work done by Cagen (1958).

Cagen was interested in explaining the long run behaviour of the currency ratio defined as currency-to-money supply over the period from 1875 to 1955 . He identified a number of factors that were expected to influence this ratio. They are as follows:

1. The opportunity cost of holding currency. 
2. Expected real income per capita.

3. The volume of retail trade (cash being more acceptable in retail trade).

4. The volume of travel per capita (cash being more acceptable between strangers).

5. The degree of urbanisation.

6. The rate of tax on transactions.

The last variable provides the link between the currency ratio and the tax evasion. According to Cagen (1958, p. 312), "some people evade taxes by making as many transactions as possible with the currency and not reporting to the tax collector". He therefore postulates a direct positive relation between the income tax rates and the currency ratio. This hypothesis was confirmed using multiple regression analysis for the period of 1919-55. The dependent variable was the ratio of currency to M2 and the independent variables were:

1. The interest rate paid on bank deposits.

2. Expected real income per capita (based of previous income levels with exponentially declining weights).

3. The annual percentage of personal income collected for income taxes.

Tanzi (1980) adopted the idea, linking the currency ratio to tax rates, and used it to derive alternative estimates of the size of the black economy for the USA.

According to Tanzi $(1980 ; 1983)$, the reason for people to engage in the underground economy is the existence of taxes. His approach focuses on the specification of a demand for currency equation to be able to see the change in the tax level on the demand.

Two assumptions on which his analysis is based are: first, the underground economy is the consequence of the high taxes; second, currency is basically used to carry out transactions or for storing wealth. Three different types of tax rates are used in the analysis. First is the personal income tax to personal income net of transfers; second, top bracket statutory tax ratio for each year; and third as a proxy for the effective weighted average rate on interest incomes, which will capture changes in the level of income taxes over the period. The model subjected to imperial test is as follows:

$$
L n C / M_{2}=a_{0}+a_{1} \ln T+a_{2} \ln W S / N I+a_{3} \ln R+a_{4} \ln Y+e \ldots \quad \ldots
$$

Where

$$
\begin{aligned}
C / M_{2} & =\text { Ratio of currency holdings to money defined as } \mathrm{M}_{2} \\
T_{1} & =\text { Ratio of personal income taxes to personal income net of transfers. } \\
T_{2} & =\text { Top bracket statutory tax rate. } \\
T_{3} & =\text { Weighted-average rate on interest income. } \\
W S / N I & =\text { Ratio of wages and salaries in national income. }
\end{aligned}
$$




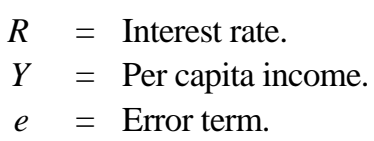

The expected sings for both per capita income and interest rate are negative. This is because economic development in the country is recognised by per capita income which is assumed to lead to the replacement of currency by cheques, thus causing a fall in $C / M_{2}$. Similarly, interest rate is negatively related because $M_{2}$ includes time deposits that offer an attractive rate of return. On the other hand, as the level of taxation rises, people are motivated to indulge in tax-evading activities that are facilitated by the use of currency - as the wages are paid in currency, especially of daily workers, and other types of income like interest payments, profits being paid by cheques. Thus an increase in wages and salaries will require more currency.

Equation 1 is estimated with each tax variable at a time, and then without taxes of any kind. The estimate of the underground economy is derived as follows. For each year, the predicted level of the currency ratio $C / M_{2}$ can be calculated by using the preceding regression equations. Then, by keeping the value of $M_{2}$ fixed, the predicted level of currency holdings can be calculated as denoted by $(C)$. This is done as follows: if the dependent variable in Equation 1 is represented by $Z_{t}$, then:

$$
\begin{aligned}
& Z_{t}=\ln \left(C / M_{2}\right)=\ln C_{t}-\ln M_{2} \\
& Z_{t}=\ln C_{t}-\ln M_{2}
\end{aligned}
$$

This equation is rewritten in terms of $C_{t}$.

$$
\operatorname{Ln} C_{t}=Z_{t}+\ln M_{2 t}
$$

Where $\wedge$ shows the value is predicted.

$$
C_{t}=\exp \left(Z_{t}+\ln M_{2 t}\right)
$$

Next, the equation is solved in the same way, assuming that the tax variable is zero while coefficients of the other variables remain unchanged. The resulting value is $C_{0}$. The difference between $C_{t}$ and $C_{0}$ shows how much taxes cause people to hold currency which gives the estimate of the illegal money. The illegal money is multiplied with the velocity of money to get an estimate of underground economy.

$$
\text { Underground economy }=\left(C_{t}-C_{0}\right) \times V
$$

The velocity of money is obtained by first finding the difference between the total currency; the demand deposits in circulation and estimated illegal money gives legal money. Dividing the GNP with legal money gives an estimate of the income velocity of legal money. It is assumed by Tanzi that the velocity of legal money is equal to that of illegal money. Tanzi (1982) had also estimated the amount of tax evasion in the 
economy by multiplying the underground economy by the ratio of taxes actually paid to measured GNP.

Tanzi's approach appears to have a sound base but has two basic flaws. First, he makes a very strong assumption that currency is used for making transactions and storing wealth in the underground economy, whereas it is observed that in the black economy cheques are used for irregular activities and even credit cards have become institutionalised means of payment for some kinds of illegal services.

Second, it is assumed that velocity of circulation of money in both sectors is the same as was assumed in Gutmann's case. Various authors like O'Higgens have questioned this assumption. However, one can find arguments a priori in favour of both lower and higher velocity of circulation in the black economy and it is not clear which, if either, view is correct.

Third, his assumption that taxes are the sole cause for the movement of resources from the formal to the black economy is criticised on the grounds that there are other variables which one would expect to influence the degree of involvement in the black economy but which have been ignored by Tanzi. For example, there may be penalties for being caught; the probability of detection; the amount of government regulation of economic activity; and so on. In spite of these drawbacks, the present analysis focuses on the replication of Tanzi's Method because it is considered to be the most sophisticated work done in the area of monetary analysis.

\section{(iv) The Currency Denomination Approach}

This approach focuses on the assumption that in underground economy bills of certain denominations are used: in the United States, as proposed by Henry (1976), bills of $\$ 100$ and above are to be withdrawn from circulation to analyse the change in the composition of total currency in circulation. Henry then attempted to measure the size of the black economy by changing the composition of total currency holdings in circulation. Furthermore, as the author has argued elsewhere, many $\$ 100$ bills are probably being used for transactions or for storing wealth in foreign countries. An unknown but probably high amount of currency substitution (with US currency replacing the currencies of many countries) has certainly been taking place over the years. This substitution or dollarisation is likely to have been significant in countries that are experiencing a high rate of inflation.

This approach is criticised by Vito Tanzi, who says that due to real growth and high inflation in the economy the currency holding would change over the years. As time would pass, large bills will not appear to be as large as before.

Philippe Barthelemy, along with the criticism above, adds that transactions in the black economy are not only settled by large denominations but also by small ones. Further, large notes are hoarded in all countries, where small denominations are used for current transactions. The small denominations infer the large. One might call it the parody of Gresham's Law. 


\section{METHODOLOGY}

Through the monetary approach those activities of the black economy are estimated that are financed through the use of currency and bearer bonds. Even if the taxes did not exist, the currency ratio would be affected by illegal and criminal activities: gambling, narcotics, smuggling, etc., are carried out through the use of currency which would increase the currency ratio. But the unavailability of the data is an obstacle to taking them into account. Thus the concentration of the study will be to capture the extent of black money, through evasion of taxes, in the form of currency and bearer bond holdings.

As mentioned earlier, the method adopted for the quantification of the black economy is that of Vito Tanzi, with some modification made in it. The model subject to empirical test is a double log specification.

$$
\operatorname{Ln} C / M 2=\alpha_{0}+\alpha_{1} \operatorname{Ln}(1+T A X / G D P)+\alpha_{2} \operatorname{Ln} I N T D P+\alpha_{3} D U M+e
$$

Where:

$C / M 2$ = Ratio of currency holdings to money supply, where money supply equals Currency+demand deposits+Time deposits+other deposits.

$T A X / G D P=$ Ratio of total tax revenue to GDP.

INTDP = Interest rate on time deposits.

$D U M=$ Taking the value 1 from 1960-71.

$e=$ Error term.

The hypothesised sign for the Tax to GDP ratio is positive, because as the level of taxes rises, people are induced to evade the payment of taxes, which is carried out through the use of currency. The relationship between the interest rate on time deposits and the currency ratio is said to be negative. This is due to the fact that a higher interest rate on time deposits will serve as an attractive incentive for investment. People would prefer to purchase time deposits rather than keep their money in cash. The rationale for choosing the dummy is to capture the effects of currency holdings of the former East and West Pakistan.

In addition to currency ratio, another dependent variable is created, which includes bearer bonds along with the currency holding. The reason for doing so is that bearer bonds serve to be a powerful source of carrying out transactions in the black economy. The bearer bonds were introduced by the government in 1984-85 to attract the black money for the enhancement of savings and investment in the economy, since they could be purchased in unlimited amounts without being asked as to where the money had come from. Thus another equation is estimated:

$$
\operatorname{Ln} C U R C B=\beta_{0}+\beta_{1} \operatorname{Ln}(1+T A X / G D P)+\beta_{2} \operatorname{Ln} I N T D P+\beta_{3} D U M+e \text { (2) }
$$


Where:

CURCB = Ratio of sum of currency holding and cumulative value of bearer bonds to $M 2$ and cumulative value of bearer bonds, i.e. (CURRENCY + CUMULATIVE VALUE OF BEARER BONDS/M2 + CUMULATIVE VALUE OF BEARER BONDS).

After the estimations of Equations 1 and 2 through Ordinary Least Square technique, the analysis of the black economy proceeds as follows.

For each year, the predicted levels of the respective ratios [CM2 \& CURCB] are derived with the tax variable $\left[C M 2_{t} \& C U R C B_{t}\right]$ and without the tax variable $\left[C M 2_{0}\right.$ and $\left.C U R C B_{0}\right]$. The difference between the tax and without-tax ratios is multiplied by the total value of $M 2$ for the respective years to obtain the level of illegal money: so illegal money for the currency ratio each year will be:

$$
\text { Illegal Money }=\left(C M 2_{t}-C M 2_{0}\right) \times M 2
$$

Similarly, for currency bearer bond ratio, it is given by:

$$
\text { Illegal Money }=\left(C U R C B_{t}-C U R C B_{0}\right) \times M 2
$$

The estimates of illegal money show how much taxes induce people to hold currency and bearer bonds in the economy. Illegal money is multiplied by the velocity of money to get the size of the black economy of each year.

Black Economy $=I M \times V$

Where:

$$
\begin{aligned}
I M & =\text { Illegal Money. } \\
V & =\text { Income velocity of money. }
\end{aligned}
$$

The velocity of money in turn is obtained from the ratio of the GNP to legal money. The legal money is evaluated by taking the difference between the total currency in circulation and illegal money. An attempt has been made to calculate the tax evasion in the economy by multiplying the estimates of black economy to ratio of overall taxes to the GNP.

\section{RESULTS}

Table 1 shows the results corresponding to Equations 1 and 2. In both cases, it can be seen that the variable interest rate on time deposits shows that the correct negative sign has turned out to be significant at 1 percent in the case of currency to $M 2$ ratio and the currency bearer bond ratio with hypothesised signs. Similarly, the Tax to GDP ratio is positive in both cases and significant at 1 percent level of significance in 
Table 1

Regression Results Corresponding to Currency Ratio and Currency Bearer Bond Ratio

\begin{tabular}{llcc}
\hline $\begin{array}{l}\text { Variable } \\
\text { Designations }\end{array}$ & $\begin{array}{c}\text { Currency Ratio } \\
(\text { CM2) }\end{array}$ & $\begin{array}{c}\text { Currency } \\
\text { Bearer Bond Ratio } \\
\text { (CURCB) }\end{array}$ \\
\hline 1 Intercept & -2.6036 & -2.8860 \\
& & $(-4.88)^{* *}$ & $(-4.29)^{* * *}$ \\
2 & INTDP & -0.3105 & -0.2576 \\
& & $(-3.16)^{* * *}$ & $(-2.63)^{* * *}$ \\
& TAX/GDP & 0.7421 & 0.8293 \\
& & $(3.16)^{* * *}$ & $(2.81)^{* * *}$ \\
& DUM & 0.1168 & 0.1606 \\
& & $(1.62)^{*}$ & $(1.76)^{*}$ \\
& R ${ }^{2}$ & 0.6675 & 0.5454 \\
& DW & 1.7292 & 1.4838 \\
& F-RATIO & 16.0541 & 9.9995 \\
N & 31 & 31 \\
\hline
\end{tabular}

*** Shows 1 percent significance.

** Shows 5 percent significance.

* Shows 10 percent significance.

Equation 1 and in Equation 2, approving the hypotheses that as the share of tax revenue to the GDP rises, the use of currency and bearer bonds in the black economy grows. The variable in both cases has shown significance. The $R^{2}$ in both cases is reasonably high and supports the fact that most of the variation in the currency ratio and the currency-bearer bond ratio is explained by the respective equations. In order to remove the auto-correlation from the regression results, the technique of auto-regressive moving averages is used.

After the estimation of these equations, the predicted value of currency holdings with and without taxes is computed. The velocity of money is multiplied by illegal currency holding to get the measure of the black economy of Pakistan as shown in Tables 2 and 3. It is seen that the black economy has been increasing over the number of years along with the tax evasion but the black economy has shown a fluctuating trend. The tables reveals that share of black economy was high during the 60s and 80s which can be attributed to high taxes and regulations imposed by the government. Point to note is that during the recent years that in late 80s from 1985-90 the black economy has started falling mainly because of the lowering of direct taxes (personal income tax and corporate tax) levied. However, the black economy still stands at about one third of the GDP according to the currency in circulation to money supply approach of Tanzi. 
When the bearer bonds are also included as a medium of exchange in the share of the black economy rises to 39 percent.

\section{CONCLUSION}

The existence of the black economy is a worrisome development for the policymakers. The documented economy is a small proportion of the national economy today. With the passage of time, the size of the black economy is expanding rapidly. The quantification of the black economy is important as it will give signals to the policymakers about the potential of the economy to generate resources.

The monetary analysis is focused to estimate the size of the black economy for 1960-90 through Vito Tanzi's approach. It is an effort to see how much of the currency in circulation along with the bearer bonds is a part of the black economy. It has been found that the black economy as a percentage of the GDP has shown a fluctuating trend. The black economy and the level of tax evasion have increased over the number of years but the black economy as a percentage of the GDP has registered a decline, which is attributed to the reduction of direct taxes, the exemptions, and the allowances given by the government.

We estimated that the revenue loss due to the presence of the black economy was between Rs 40 to Rs 45 billion in 1989-90. This is a sizeable magnitude and indicates that substantial revenue gains can be realised by reducing the extent of tax evasion in the economy. In the case of Pakistan, the estimation of the black economy through this approach is a pioneering effort and we hope that, in the future, researchers will modify this approach and discover new methods to measure the size of the black economy.

\section{REFERENCES}

Feige, Edgar L. (1979) How big is Irregular Economy? Challenge. Nov.-Dec.

Guttman, Peter M. (1977) The Subterranean Economy. Financial Analysts Journal 2634. Nov-Dec.

Tanzi, Vito (1980) The Underground Economy in the United States: Estimates and Implications. Banca Nazionale Del Lavaro. (Quarterly Review). Dec.

Tanzi, Vito (1982) A Second (and More Skeptical) Look at the Underground Economy. In Vito Tanzi (ed) The Underground Economy in the United States and Abroad. Lexington, MA: Lexington Books.

Tanzi, Vito (1982) Underground Economy and Tax Evasion in the United States: Estimates and Implications. In Vito Tanzi (ed) The Underground Economy in the United States and Abroad. Lexington,, MA: Lexington Books.

Tanzi, Vito, (1983) The Underground Economy in the United States: Annual Estimates 1930-1980. Staff Papers. 3:2 283-305. 